\title{
FACTORS RELATED TO DEFAULTERS OF TUBERCULOSIS PATIENTS IN DOTS PROGRAM IN WARANGAL DISTRICT
}

\author{
Tagaram Ramchandra ${ }^{1}$, Punam Kumari Jha' ${ }^{2}$, K. Bhavani ${ }^{3}$, N. Pragathi Kumar ${ }^{4}$ \\ ${ }^{1}$ Senior Resident, Department of Community Medicine, Kakatiya Medical College, Warangal. \\ ${ }^{2}$ HOD \& Professor, Department of Community Medicine, Kakatiya Medical College, Warangal. \\ ${ }^{3}$ Associate Professor, Department of Community Medicine, Kakatiya Medical College, Warangal. \\ ${ }^{4}$ Post Graduate, $2^{\text {nd }}$ Year, Department of Community Medicine, Kakatiya Medical College, Warangal.
}

\section{ABSTRACT}

\section{OBJECTIVES}

1. To determine the multiple factors responsible for defaulters of tuberculosis in DOTS.

2. To compare factors among defaulters in relation to urban, rural and tribal TB units.

\section{METHODOLOGY}

A cross-sectional study was conducted among defaulters of TB patients in 3 TB units out of 7 TB units in Warangal District during July 2013 to May 2014. The area covered by the 3 TB units consisting of urban area, rural area and tribal area attached to district Tuberculosis Centre. A pre-structured and pretested questionnaire was used to collect the data by "Interview technique."

\section{RESULTS}

In the present study, out of 106 defaulters majority were males $82.1 \%$ and $69.8 \%$ were in the age group of $26-55$ yrs. which is economically productive years of life. Illiterates $37.7 \%, 20.7 \%$ were primarily educated and most of illiterates were in tribal area, (50\%); $37.7 \%$ were unskilled workers, $68 \%$ belonged to upper lower and lower class, $90.6 \%$ of defaulters took treatment for only 2-3 months. Among comorbidities, diabetes was more common and also with HIV. Consumption of alcohol present in $70.8 \%$ and associated with default from treatment.

\section{CONCLUSION}

In DOTS defaulters, feeling well after 1-3 months of treatment and lack of knowledge about disease and treatment course period, side effects, habit of alcohol, initial private treatment, stigma, poverty and no food are the common factors to default from their treatment.

\section{KEYWORDS}

Defaulters, DOTS, Tuberculosis.

HOW TO CITE THIS ARTICLE: Tagaram Ramchandra, Punam Kumari Jha, K. Bhavani, N. Pragathi Kumar. "Factors Related to Defaulters of Tuberculosis Patients in Dots Program in Warangal District." Journal of Evolution of Medical and Dental Sciences 2015; Vol. 4, Issue 101, December 17; Page: 16617-16621, DOI: 10.14260/jemds/2015/2479

\section{INTRODUCTION}

Tuberculosis (TB) is a major public health problem in the world with an estimated global incidence rate of 122 cases per 100,000 populations in $2012 .{ }^{1}$ It causes ill-health among millions of people each year and ranks as the second leading cause of death from an infectious disease worldwide after Human Immunodeficiency Virus. ${ }^{2}$ The latest estimates are that there were almost 8.6 million new cases in 2012 and 1.3 million TB deaths. Most of these TB cases and deaths occur among men. In 2012 there were an estimated 2.9 million cases and 410,000 TB deaths among women as well as an estimated 530,000 cases and 74,000 deaths among children. ${ }^{3}$

The WHO South-East Asia Region with an estimated 4.8 million prevalent cases and about 3.4 million incident cases and 4,50,000 deaths in 2012 carries about 39.5\% morbidity and $48 \%$ mortality of the global burden of tuberculosis. Out of 22 high burden countries, India accounting for $26 \%$ of the world's incident cases. ${ }^{4}$

Financial or Other, Competing Interest: None.

Submission 24-11-2015, Peer Review 25-11-2015,

Acceptance 11-12-2015, Published 16-12-2015.

Corresponding Author:

Dr. Punam Kumari Jha,

House. No. 1-8-714, Flat No. A-1,

Green Square Apartment,

Balasamudram, Warangal,

Telangana State, India.

E-mail: drpunamjha@yahoo.co.in

DOI:10.14260/jemds/2015/2479
Poverty and tuberculosis are intimately connected. Death of one person for every two minutes in India (750 deaths everyday). ${ }^{5}$ Tuberculosis is a social disease with medical aspects. ${ }^{6}$ The available therapeutic regimens have inherent disadvantage of long treatment duration, results in patient's non-compliance and yields the risk of having the drug resistance. Hence new modalities of treatment that are potent active resistant against strain are needed to combat these diseases. $^{7}$

\section{MATERIALS AND METHODS}

A cross-sectional study was conducted in 3 TB units, out of 7 TB units in Warangal District. Area covered by 3 TB units consist of Warangal TU (urban), Geesukonda TU (rural), Govindaraopet TU (tribal), attached to District Tuberculosis Centre (DTC) from July 2013 to May 2014. Lottery method was adopted for selecting three TB units $(40 \%)$ out of seven in Warangal District. One TU from urban, one TU from rural and one TU from tribal area. For this study, only defaulters of DOTS who were enrolled in TB registers of concerned TB units were taken as study sample from selected TB units. The addresses of defaulters of DOTs were obtained from TB registers of concerned TB units. In 2013, total TB cases were registered in selected TUs were 1566 and 116 defaulters among them. The patients were contacted at their homes and informed about the study and obtained data from 106 defaulters (After excluding 5 migrated, 3 absconded and 2 died). Method adopted to obtain data has been the "Interview technique." 
Written consent was brought from each study participant after prospective participants had been fully informed on how the study would be carried out and how the collected data would be handled to ensure confidentiality and privacy. Each participant had a right to refuse to participate. A pretested and structured questionnaire was used to collect the data.

\section{Topography of the District}

Warangal District headquarters is situated at distance of 146 Kms. from Hyderabad City (Telangana) consists of 3 cities Warangal, Hanamkonda and Kazipet. DTC is $9 \mathrm{kms}$ away from Kazipet Railway Junction from where different trains go to North, West and South India. The District Tuberculosis Centre has 7 TB units (TUs) and each is attached with 5 to 6 microscopy centres. Urban TU located at DTC, Warangal. Rural and Tribal TU areas located at a distance of $100 \mathrm{~km}$ from DTC. DTC covers total of 1097 villages.

\section{RESULTS}

In this study majority of defaulters were males, i.e. $82.1 \%$. Females were more in $10-25$ yrs. of age; $59.4 \%$ had stopped drugs for feeling well after 1-3 months, lack of knowledge (43.4\%), side effects (39.6\%) and alcohol (38.7\%). And factors like initial private treatment $34 \%$, stigma $26.4 \%$, poverty $25.5 \%$, cost of travel $16 \%$ and many defaulters had more than one reason to stop anti-TB treatment. Majority were illiterates $(37.7 \%)$ followed by primary education.

Illiterates were more in tribal area (50\%). Among the study population $37.7 \%$ were unskilled workers followed by unemployed $21.7 \%$. Among the defaulters with comorbidities, Diabetes $(10.4 \%)$ was more common and 5.7\% HIV. In this study, there were several responses from the patients when they were asked their opinion on what could be done to help TB patients complete their treatments. Most of defaulters told that provision of food (38.7\%) followed by treatment for other diseases at same Centre, admission in hospital and incentives to their family along with medicine will be the better way to reduce defaults as most of them belongs to lower socioeconomic status.

\begin{tabular}{|c|c|c|c|}
\hline \multicolumn{4}{|c|}{ AGE AND SEX DISTRIBUTION AMONG STUDY } \\
POPULATION \\
\hline \multirow{2}{*}{ Age } & \multicolumn{2}{|c|}{ Sex } & \multirow{2}{*}{ Total } \\
\cline { 2 - 3 } & Female & Male & \\
\hline $10-25 y r s$ & $7(6.6 \%)$ & $6(5.7 \%)$ & $13(12.3 \%)$ \\
\hline $26-39 y r s$ & $6(5.7 \%)$ & $29(27.4 \%)$ & $35(33.0 \%)$ \\
\hline $40-55 y r s$ & $4(3.8 \%)$ & $35(33.0 \%)$ & $39(36.8 \%)$ \\
\hline $56-70 y r s$ & $2(1.9 \%)$ & $17(16.0 \%)$ & $19(17.9 \%)$ \\
\hline Total & $\mathbf{1 9 ( 1 7 . 9 \% )}$ & $\mathbf{8 7}(\mathbf{8 2 . 1 \% )}$ & $\mathbf{1 0 6}(\mathbf{1 0 0} \%)$ \\
\hline
\end{tabular}

Chi-Square $=13.683 \mathrm{df}=3 \mathrm{p}=0.003$

\begin{tabular}{|c|c|c|c|}
\hline \multicolumn{4}{|c|}{ REASONS FOR DEFAULT/DRUG INTERRUPTION } \\
AMONG STUDY POPULATION \\
\hline $\begin{array}{c}\text { Reasons To } \\
\text { Stop anti-TB } \\
\text { treatment }\end{array}$ & Yes & No & Total \\
\hline $\begin{array}{c}\text { Feeling Well } \\
\text { After 1-3 } \\
\text { Months }\end{array}$ & $63(59.4 \%)$ & $43(41.6 \%)$ & $106(100 \%)$ \\
\hline $\begin{array}{c}\text { Lack of } \\
\text { Knowledge }\end{array}$ & $46(43.4 \%)$ & $60(56.6 \%)$ & $106(100 \%)$ \\
\hline Side Effects & $42(39.6 \%)$ & $64(60.4 \%)$ & $106(100 \%)$ \\
\hline Alcohol & $41(38.7 \%)$ & $66(61.3 \%)$ & $106(100 \%)$ \\
\hline $\begin{array}{c}\text { Initial Private } \\
\text { Treatment }\end{array}$ & $36(34 \%)$ & $70(66 \%)$ & $106(100 \%)$ \\
\hline Stigma & $28(26.4 \%)$ & $78(73.6 \%)$ & $106(100 \%)$ \\
\hline Poverty & $27(25.5 \%)$ & $79(74.5 \%)$ & $106(100 \%)$ \\
\hline
\end{tabular}

\begin{tabular}{|c|c|c|c|}
\hline Cost of Travel & $17(16 \%)$ & $89(84 \%)$ & $106(100 \%)$ \\
\hline $\begin{array}{c}\text { Not Feel Better } \\
\text { On Medicine }\end{array}$ & $17(16 \%)$ & $89(84 \%)$ & $106(100 \%)$ \\
\hline $\begin{array}{c}\text { Lack of Family } \\
\text { Support }\end{array}$ & $14(13.2 \%)$ & $92(86.8 \%)$ & $106(100 \%)$ \\
\hline No Food & $11(10.4 \%)$ & $95(89.6 \%)$ & $106(100 \%)$ \\
\hline $\begin{array}{c}\text { Too Many } \\
\text { Tablets }\end{array}$ & $7(6.6 \%)$ & $99(93.4 \%)$ & $106(100 \%)$ \\
\hline $\begin{array}{c}\text { Inadequate } \\
\text { Supply of } \\
\text { Medicine }\end{array}$ & $5(4.7 \%)$ & $101(95.3 \%)$ & $106(100 \%)$ \\
\hline $\begin{array}{c}\text { Others } \\
\text { (Migration, } \\
\text { Pregnancy, } \\
\text { Etc.) }\end{array}$ & $4(3.8 \%)$ & $102(96.2 \%)$ & $106(100 \%)$ \\
\hline
\end{tabular}

Feeling Well After 1-3 Months of Treatment as a Reason to Stop the Treatment among Study Population of 3 Tb Units

\begin{tabular}{|c|c|c|c|c|}
\hline $\begin{array}{c}\text { Feeling } \\
\text { well after } \\
\mathbf{1 - 3} \\
\text { months } \\
\text { treatment }\end{array}$ & $\begin{array}{c}\text { Warangal } \\
\text { (Urban) }\end{array}$ & $\begin{array}{c}\text { Thorrur } \\
\text { (Rural) }\end{array}$ & $\begin{array}{c}\text { Govindaraopet } \\
\text { (Tribal) }\end{array}$ & Total \\
\hline Yes & $\begin{array}{c}15 \\
(14.1 \%)\end{array}$ & $\begin{array}{c}21 \\
(19.8 \%)\end{array}$ & $\begin{array}{c}27 \\
(25.4 \%)\end{array}$ & $\begin{array}{c}63 \\
(59.4 \%)\end{array}$ \\
\hline No & $\begin{array}{c}19 \\
(17.9 \%)\end{array}$ & $\begin{array}{c}14 \\
(13.2 \%)\end{array}$ & $\begin{array}{c}10 \\
(9.43 \%)\end{array}$ & $\begin{array}{c}43 \\
(40.6 \%)\end{array}$ \\
\hline Total & $\mathbf{3 4 ( 3 2 \% )}$ & $\mathbf{3 5 ( 3 3 \% )}$ & $\mathbf{3 7 ( 3 5 \% )}$ & $\begin{array}{c}\mathbf{1 0 6} \\
(\mathbf{1 0 0} \%)\end{array}$ \\
\hline
\end{tabular}

Chi-Square $=6.126, \mathrm{df}=2, \mathrm{p}<0.047$

Lack of knowledge as a reason to stop Anti-TB treatment in Tus:

\begin{tabular}{|c|c|c|c|c|}
\hline $\begin{array}{c}\text { Knowledge } \\
\text { about } \\
\text { treatment } \\
\text { course } \\
\text { period }\end{array}$ & $\begin{array}{c}\text { Warangal } \\
\text { (Urban) }\end{array}$ & $\begin{array}{c}\text { Thorrur } \\
\text { (Rural) }\end{array}$ & $\begin{array}{c}\text { Govindaraopet } \\
\text { (Tribal) }\end{array}$ & Total \\
\hline Yes & $\begin{array}{c}26 \\
(24.5 \%)\end{array}$ & $\begin{array}{c}20 \\
(17.9 \%)\end{array}$ & $14(13.2 \%)$ & $\begin{array}{c}60 \\
(56.6 \%)\end{array}$ \\
\hline No & $9(7.5 \%)$ & $\begin{array}{c}16 \\
(15.1 \%)\end{array}$ & $21(19.8 \%)$ & $\begin{array}{c}46 \\
(43.4 \%)\end{array}$ \\
\hline Total & $\mathbf{3 5 ( 3 2 \% )}$ & $\mathbf{3 ( 3 3 \% )}$ & $\mathbf{3 5 ( 3 5 \% )}$ & $\begin{array}{c}\mathbf{1 0 6} \\
\mathbf{( 1 0 0 )}\end{array}$ \\
\hline
\end{tabular}

Chi-Square $=8.399, \mathrm{df}=2, \mathrm{p}<0.015$

Initial Private Treatment as a Reason to Stop Anti-Tb Treatment

\begin{tabular}{|c|c|c|c|c|}
\hline $\begin{array}{c}\text { H/o } \\
\text { Initial } \\
\text { Private } \\
\begin{array}{c}\text { Treat- } \\
\text { ment }\end{array}\end{array}$ & $\begin{array}{c}\text { Warangal } \\
\text { (Urban) }\end{array}$ & $\begin{array}{c}\text { Thorrur } \\
\text { (Rural) }\end{array}$ & $\begin{array}{c}\text { Govinda } \\
\text { raopet } \\
\text { (Tribal) }\end{array}$ & \multirow{2}{*}{ Total } \\
\hline Yes & $17(16 \%)$ & $12(11.3 \%)$ & $7(6.6 \%)$ & $36(33.9 \%)$ \\
\hline No & $17(16 \%)$ & $23(21.7 \%)$ & $30(28.4 \%)$ & $70(66.1 \%)$ \\
\hline Total & $\mathbf{3 4 ( 3 2 \% )}$ & $\mathbf{3 5}(\mathbf{3 3 \% )}$ & $\mathbf{3 7 ( 3 5 \% )}$ & $\begin{array}{c}\mathbf{1 0 6}(\mathbf{1 0 0} \\
\mathbf{\%})\end{array}$ \\
\hline
\end{tabular}

Chi-Square $=7.634, \mathrm{df}=2, \mathrm{p}<0.022$

Alcoholism, As a Reason to Stop Anti-Tb Treatment in 3 Tb Units

\begin{tabular}{|c|c|c|c|c|}
\hline \multirow{2}{*}{$\begin{array}{c}\text { Alcohol, } \\
\text { a reason } \\
\text { to stop } \\
\text { treatment }\end{array}$} & $\begin{array}{c}\text { Warangal } \\
\text { (Urban) }\end{array}$ & $\begin{array}{c}\text { Thorrur } \\
\text { (Rural) }\end{array}$ & $\begin{array}{c}\text { Govindaraopet } \\
\text { (Tribal) }\end{array}$ & \multirow{2}{*}{ Total } \\
\hline Yes & $8(7.5 \%)$ & $13(12.3 \%)$ & $20(18.9 \%)$ & $41(38.7 \%)$ \\
\hline No & $26(24.5 \%)$ & $22(20.7 \%)$ & $17(16.1 \%)$ & $65(61.3 \%)$ \\
\hline Total & $\mathbf{3 4 ( 3 2 \% )}$ & $\mathbf{3 5 ( 3 3 \% )}$ & $\mathbf{3 7 ( 3 5 \% )}$ & $\mathbf{1 0 6 ( 1 0 0 \% )}$ \\
\hline
\end{tabular}

Chi-Square $=7.012, \mathrm{df}=2, \mathrm{p}<0.030$ 
Knowledge of $\mathrm{Tb}$ Treatment Duration among Study Population According to Their Previous Place of Treatment

\begin{tabular}{|c|c|c|c|c|}
\hline $\begin{array}{c}\text { Duration } \\
\text { Of TB } \\
\text { Treatment }\end{array}$ & $\begin{array}{c}\text { Private } \\
\text { Hospital }\end{array}$ & $\begin{array}{c}\text { (Govt. } \\
\text { Higher } \\
\text { Centres } \\
\text { \& PHC) }\end{array}$ & $\begin{array}{c}\text { Other } \\
\text { Medicine }\end{array}$ & Total \\
\hline 6 months & $8(7.5 \%)$ & $\begin{array}{c}24(22.6 \\
\%)\end{array}$ & $1(0.9 \%$ & $33(31.1 \%)$ \\
\hline $\begin{array}{c}\text { Until feeling } \\
\text { well }\end{array}$ & $10(9.4 \%)$ & $\begin{array}{c}12(11.3 \\
\%)\end{array}$ & $7(6.6 \%)$ & $29(27.4 \%)$ \\
\hline $\begin{array}{c}\text { Until doctor/ } \\
\text { health } \\
\text { worker's } \\
\text { advice }\end{array}$ & $4(3.8 \%)$ & $\begin{array}{c}10(9.4 \% \\
)\end{array}$ & $43.8 \%$ & $18(17 \%)$ \\
\hline $\begin{array}{c}\text { No idea (Do } \\
\text { not know) }\end{array}$ & $14(13.2 \%)$ & $\begin{array}{c}11(10.4 \\
\%)\end{array}$ & $1(0.9 \%)$ & $26(24.5 \%)$ \\
\hline Total & $\mathbf{3 6 ( 3 4 \% )}$ & $\begin{array}{c}\mathbf{5 7} \\
\mathbf{\%})\end{array}$ & $\begin{array}{c}\mathbf{1 3 ( 1 2 . 3 \%} \\
\mathbf{j}\end{array}$ & $\begin{array}{c}\mathbf{1 0 6}(\mathbf{1 0 0} \\
\mathbf{\%})\end{array}$ \\
\hline
\end{tabular}

History of Taking Alcohol among Study Population

\begin{tabular}{|c|c|c|c|}
\hline \multirow{2}{*}{ Age } & \multicolumn{2}{|c|}{ Alcohol } & \multirow{2}{*}{ Total } \\
\cline { 2 - 3 } & Yes & No & \\
\hline $10-39$ yrs. & 27 & 21 & $48(45.3 \%)$ \\
\hline $40-70$ yrs. & 47 & 11 & $58(54.7 \%)$ \\
\hline Total & $\mathbf{7 4 ( 7 0 . 8 \% )}$ & $\mathbf{3 2 ( 2 9 . 2 \% )}$ & $\mathbf{1 0 6}(\mathbf{1 0 0 . 0 \% )}$ \\
\hline
\end{tabular}

Chi-square $=7.655, \mathrm{df}=2, \mathrm{p}<0.010$

\begin{tabular}{|c|c|c|c|c|}
\hline \multicolumn{5}{|c|}{ Opinions of Patients to Complete Their Treatment in 3 Tus } \\
\hline \multirow[b]{2}{*}{$\begin{array}{l}\text { Patient's } \\
\text { Opinion }\end{array}$} & \multicolumn{3}{|c|}{ Name of TB unit } & \multirow[b]{2}{*}{ Total } \\
\hline & $\begin{array}{c}\text { Warangal } \\
\text { (Urban) }\end{array}$ & $\begin{array}{c}\begin{array}{c}\text { Thorrur } \\
\text { (Rural) }\end{array} \\
\end{array}$ & $\begin{array}{c}\text { Govindaraopet } \\
\text { (Tribal) }\end{array}$ & \\
\hline $\begin{array}{c}\text { Provision } \\
\text { of Food }\end{array}$ & 10 & 13 & 18 & 41(38.7\%) \\
\hline $\begin{array}{c}\text { Treatment } \\
\text { For Other } \\
\text { Diseases } \\
\text { At Same } \\
\text { Centre }\end{array}$ & 8 & 5 & 6 & 19(17.9\%) \\
\hline More Staff & 6 & 5 & 6 & $17(16.1 \%)$ \\
\hline $\begin{array}{c}\text { Admission } \\
\text { In } \\
\text { Hospital }\end{array}$ & 6 & 6 & 4 & 16(15.1\%) \\
\hline $\begin{array}{l}\text { Incentives } \\
\text { To Family }\end{array}$ & 4 & 6 & 3 & $13(12.3 \%)$ \\
\hline Total & 34 & 35 & 37 & $106(100 \%)$ \\
\hline
\end{tabular}

\section{DISCUSSION}

In the present study $36.8 \%$ of TB patients were in the age group of 40-55 years, followed by $33.0 \%$ of TB patients in the age group of 26-39 years, which is known to be the most economically productive period of life. Mahesh Kumar et al. found that age group between 35-44 years was more noncompliant which happened to be similar to this study finds, which is $25.4 \% .^{8}$ Pranab Chatterjee et al. found that defaulter significantly increased with age. Maximum age was being in $45-49$ years. ${ }^{9}$

In the present study among the 106 patients from Warangal (Urban), Thorrur (Rural) and Govindaraopet (Tribal), males 87(87.9\%) were more than females $19(17.1 \%)$. A study in Dindigul and Puducherry Districts of Tamil Nadu in 2010 reported that among defaulters males were $(78 \%)$ more than females (22\%). ${ }^{10}$ In the present study majority of defaulters in this study were $39.6 \%$ of the defaulters were unskilled workers (daily labour), 19.8\% unemployed. Unemployment, being a pensioner, homelessness and overcrowded living conditions were revealed as important default predictors (Jakubowiak et al. 2007; Hasker et al. 2008). ${ }^{11}$
In the present study illiterates $37.7 \%, 20.7 \%$ were primarily educated and most of illiterates were in tribal area, (50\%). Among defaulters, urban area had fewer illiterates than tribal area. Literacy has a bearing on the diagnosis and treatment of TB patients. Vijay kumar et al. and Chadha SL have indicated in their study. ${ }^{12}$

In the present study, socio-economic status majority of defaulters in this study was $68 \%$ were upper lower and lower class. Besides the disease burden, TB also causes an enormous socio-economic burden as most of them were unskilled workers (Daily labour) and most of them were in productive years of life (26-55 years). According to Lamsal et al. (2009:26), poverty and TB are closely connected. The poor have higher contact rates due to crowded homes, more active infection due to sub-optimal nutrition and working conditions, they may have less flexibility regarding work and clinic attendance and less ability to pay for medications and transport. ${ }^{13}$

In this study, $70.8 \%$ of defaulters were alcoholics. This habit increases with age. The observed difference between age groups was found to be statistically significant $(\mathrm{p}<0.010)$ These findings are not consistent with a study in Dindigul and Puducherry Districts of Tamil Nadu in 2010, found that more than half $(70.75 \%)$ of the patients did not consume alcohol, $(29.25 \%)$ patients had the habit of consuming alcohol.10

In this study also $74 \%$ treatment interruption occurred during continuation phase of treatment. In other studies in India $20 \%$ defaulted, out of them $91 \%$ treatment interruption occurred during continuation phase of treatment. ${ }^{14}$

In the present study feeling well after 1-3 months of treatment, lack of knowledge, side effects with drugs, initial private treatment, alcohol, stigma, cost of travel, no proper food, lack of family support and others were the main reasons. Among the various reasons for defaulting, the important ones were indifference after improvement in symptoms, distance from treatment centre and lack of motivation. A variety of other reasons have been stated by other workers, such as family events, financial difficulty, carelessness, forgetfulness, lack of time, etc. 15

In this study most common reason for default from treatment is feeling well after 1-3 months of treatment. Among the study participants it was a reason for default of treatment seen more in tribal area $(25.4 \%)$. The observed difference between 3 study populations was found to be statistically significant $(\mathrm{p}<0.047)$. Demissie and Kebede 1994; Jaiswal et al. 2003; Bam et al. 2006; Shargie and Lindtjorn 2007 studies reported that default has been linked to the length and complexity of treatment as well as to the fact that most patients feel markedly better after the first or second month of treatment. 16

In the present study, $43 \%$ of defaulters did not have knowledge about disease and treatment course period. Illiterates were more in tribal TU as compared to rural and urban TUs. The observed difference between groups was found to be statistically significant $(\mathrm{p}<0.015)$.

Finlay et al. (2012:5) reported that cases in their study conducted in South Africa were more likely to report that they had not received enough education about TB at the beginning of their treatment, that they were not told why treatment would take six or more months and lacked counsel and information about TB treatment in general. ${ }^{17}$ In the present study, $90.6 \%$ of study participants experienced side effects of which vomiting and abdominal pain (GI upset) was most common (49.1\%) followed by giddiness (43.4\%). Most of them experienced more than one side effect. This is consistent with a study conducted in Ethiopia by Tekle et al. (2002) found side effects to be statistically significant (OR: 4.20 , CI: 1.51, 11.66) predictors of default. 18 
The present study showed that $53.6 \%$ were diagnosed at Govt. Health Centres, $34.9 \%$ were at private hospitals and $12.26 \%$ were diagnosed at other sectors (traditional healers) Similar findings in a cross-sectional study done in Ethiopia by Wondimu, Michael, Kassahun et al. (2007:149-150) showed that in general $35.6 \%$ of patients reported first to drug shops, private clinics or private hospitals upon recognition of symptoms; $40 \%$ of patients reported first to either health centres or government hospitals and $4.1 \%$ reporting first to traditional/spiritual healers. ${ }^{19}$

In this study population with $\mathrm{H} / \mathrm{o}$ initial private treatment as a reason for default, which was seen more in urban area as compared to tribal area. The observed difference between 3 groups was found to be statistically significant $(p<0.022)$. The private sector in India is highly unorganized with a lack of regulation in both prescribing practices as well as the qualifications of those prescribing anti-TB drugs without being qualified to do so. 20

In this study alcohol $70.8 \%$ had habit of alcohol and also a reason to default. Statistically significant difference was present between urban, rural, tribal study groups $(\mathrm{p}<0.030)$. This is similar with other studies, alcohol abuse, smoking and substance abuse such as smoking hallucinogens like cannabis is associated with TB default (Lönnroth et al. 2008 and Pinidiyapathirage et al. 2008). ${ }^{21-22}$ In present study $26.4 \%$ respondents did not disclose their TB status to anyone giving "No one to trust" and "Fear of being isolated by family and friends" as the reasons. Disclosure status did not show any significant difference between the 3 study groups. Kaona et al. (2006:68) study reported stigma and discrimination of TB patients as affecting treatment compliance. ${ }^{23}$

In the present study, $6.6 \%$ of patients defaulted due to too many tablets as many of them had other comorbidities. A study by Gebremariam et al. (2010:4) showed that patients attributed pill burden to be one of the major challenges to treatment. They used expressions such as "Becoming a drug bag" and "Becoming a pharmacy." 24 In present study $3.8 \%$ of patients defaulted due to other reasons (Migration, pregnancy, etc.) and migration was mainly due to work related reasons. In a study of Jaggarajamma, Muniyandi, Chandrasekaran, Sudha, et al. (2005:35) confirmed that their study showed that migration was a significant factor for treatment default $(24 \%$ of the defaulters had migrated) in Tamil Nadu. ${ }^{25}$ In this study in defaulters with comorbidities, Diabetes $(10.4 \%)$ is more common.

In the present study there were several responses from the patients when they were asked their opinion on what could be done to help TB patients complete their treatments; 38.7\% of defaulters wanted food to be made available for patients taking treatments followed by $17.9 \%$ wanted medicines to be provided in one place for those with other comorbidities; $16 \%$ wanted more staff at TB clinic; $15.1 \%$ of patients to admit in hospital until they complete treatment; and $12.3 \%$ asked to provide incentives to family to complete their treatment.

The patient responses reinforced the need to address food shortages and also to improve economic status as most of them unskilled workers and belong to upper lower and lower socio-economic status.

\section{CONCLUSION AND SUMMARY}

Thus from the above findings it can be concluded that default is a major barrier in the success of RNTCP program. It was observed that operational factors such as feeling well after 13 months of anti-TB treatment, lack of knowledge, side effects, alcohol, initial private treatment, stigma, poverty, lack of family support, no food, too many tablets, inadequate supply of medicine and others (Migration etc.) were associated with defaulting. Patient factors such as lack of knowledge on treatment duration, migration, male sex, occupation and literacy status had a bearing on the behavior of defaulting. Literacy, economic status, knowledge about disease and treatment course period was low in tribal TU area as compared to rural and urban TU areas. Tuberculosis is an infectious disease and it has a devastating impact on the economic well-being of individual, their families. TB is one of the major public health problems in India. It is important to study and understand the magnitude of risk factors for defaults of treatment in TB patients is an important work for making policies, programmes and strategies.

\section{REFERENCES}

1. WHO Global TB Report 2013. PubMed | Google Scholar.

2. World Health Organization. Global tuberculosis report 2014 Geneva. World Health Organization. Google Scholar.

3. Park text book of social and preventive medicine; $22^{\text {nd }}$ edition, 5; 1; 167 (India).

4. World Health Organization, annual TB report 2014, epidemiology of TB in South East Asian Region 2; 4.

5. Indian journal of tuberculosis-2014; default factors among tuberculosis patients $61 ; 2$.

6. Rieder LH. 2002:51 text book "Interventions for Tuberculosis Control and Elimination." International Union against Tuberculosis and Lung Diseases.

7. Komuram Balu, Punam Kumara Jha. "A Study of Defaulters of Dots In Warangal District of Andhra Pradesh." Journal of Evolution of Medical and Dental Sciences, volume 2, issue 38, September 23, 2013, page no. 7234.

8. Mahesh Kumar, JV Singh, AK et al. Factor affecting the noncompliance in DOTs in Lucknow District, Indian Journal of Community Medicine, Vol. XXVII, No.3, Jul., Sept., 2002.

9. Pronab Chatterjee1, Bratati Banerjee2, Debashish Dutt3, et al. A comparative evaluation of factors and reasons for defaulting in tuberculosis treatment in the states of West Bengal, Jharkhand and Arunachal Pradesh in 2003.

10. Dr. Tanga Vignesh. A comparative study of risk factors for default and treatment interruptions among RNTCP Category Ii Patients in Puducherry and Dindigul, Tamilnadu, 2010.

11. Jakubowiak WM, Bogorodskaya EM, Borisov SE, et al. 2007. Risk factors associated with default among new pulmonary TB patients and social support in six Russian regions. Int J Tuberc Lung Dis [Online], 11(1):46-53. (Accessed 14 October 2010).

12. Vijay Kumar, et al. Risk factors associated with default among new smear positive TB patients treated under DOTS in India. Plos ONE. April 2010;4(5): E10043 and Chadha SL, Bhagi RP. Treatment outcome in tuberculosis patients placed under Directly Observed Treatment Short Course (DOTS) - A Cohort Study. Ind J Tub. 2000;(47):1558. Have indicated in their study literacy has a bearing on the diagnosis and treatment of TB patients.

13. Lamsal DK, Lewis OD, Smith S, et al. 2009. Factors related to defaulters and treatment failure of TB patients in the DOTS program in the Sunsari District of Eastern Nepal SAARC Journal of TB, Lung Diseases \& HIV/AIDS 6(1):2530.

[http://www.nepjol.info/index.php/SAARCTB/article/vie w/3061].16 June 2012.

14. Www.plosmedicine.org/article/ infor.doi/10.1371/journal.

15. Kashyap M. Socio-cultural context of TB treatment: A case study of Southern Gujarat Ind. J Tub 1977;24(2):87.

16. Demissie M and Kebede D. "Defaulting from tuberculosis treatment at the Addis Abeba tuberculosis centre and factors associated with it," Ethiopian Medical Journal, vol. 32, no. 2, pp. 97-106, 1994. 
17. Finlay A, Lancaster J, Holtz TH, Weyer K, Miranda A and Van Der Walt M. 2012. Patient and provider-level risk factors associated with default from TB treatment, South Africa, 2002: A case-control study. BioMed Central 12(56). [Online]. Available:

[http://www.biomedcentral.com/1471-2458/12/56/]. 1 June 2012.

18. Tekle B. ${ }^{1}$; Mariam DH.2; Ali A. Study on defaulting from DOTS and its determinants in three districts of Arsi Zone in Ethiopia. The International Journal of Tuberculosis and Lung Disease, Volume 6, Number 7, July 2002, pp. 573-579(7).

19. Wondimu T, Michael KW, et al. 2007. Delay in initiating TB treatment and factors associated among pulmonary TB patients in East Wollega, Western Ethiopia. Ethiopian Journal Health Dev. 21(2):149-156. [http://ejhd.uib.no/ejhd2/148_156_EJHD_Vol_212148_15 6_EJHD_Vol_21-2.pdf].

20. WHO Report 2009. Global Tuberculosis Control. Epidemiology, Strategy and Financing. Geneva: World Health Organization; 2009.

21. Lönnroth K, Williams BG, Stadlin S, et al. 2008. Alcohol Use as a risk factor for tuberculosis- A Systematic Review BMC Public Health, Available at WWW: http://www.medscape.com/viewarticle (14 August 2009).
22. Pinidiyapathirage J, Senaratne W, et al. 2008. Prevalence and predictors of default with tuberculosis treatment in Sri Lanka. BMJ 39(6):1076-1082.

23. Kaona FAD, Tuba M, Siziya S, et al. 2004. An assessment of factors contributing to treatment adherence and knowledge of TB transmission among patients on TB treatment. BMC Public Health [Online], (4)68:1471-2458. Available at WWW: http://www.biomedcentral.com (Accessed 6 October 2010).

24. Gebremariam MK, Bjune GA and Frich JC 2011. Lay beliefs of TB and TB/HIV co-infection in Addis Ababa, Ethiopia: A qualitative study. BMC Research Notes 4(277). Available: [http://www.ncbi.nlm.nih.gov/pubmed/21813004]. 12 June 2012.

25. 101. Jaggarajamma $K$, Muniyandi $M$, Chandrasekara V, Sudha GA, Thomas PG, Gopi PG, et al. 2005. Is migration a factor leading to default under RNTCP? Indian Journal of TB 53: 33-36. [Online]. Available: [http://medind.nic.in/ibr/t06/i1/ibrt06i1p33.pdf]. 11 June 2012. 